\title{
STUDI KOMPARASI KUALITAS KEHIDUPAN KERJA PERAWAT TERHADAP MUTU PELAYANAN KEPERAWATAN ANTARA RUMAH SAKIT AN-NISA TANGERANG DAN RUMAH SAKIT PELABUHAN JAKARTA 2019
}

\author{
*Veri, **Muhammad Hadi \\ Program Studi S1 Keperawatan, STIKes Widya Dharma Husada Tangerang \\ Jalan Pajajaran No1, Pamulang Tangerang Selatan Banten \\ stefenveri060991@wdh.ac.id
}

\begin{abstract}
ABSTRAK
Latar Belakang: Kualitas kehidupan kerja adalah suatu upaya tinggi rendahnya para pegawai dapat meningkatkan kehidupan pribadi mereka melalui pelaksanaan pekerjaan di lingkungan kerjanya. Presentasi perawat yang keluar ( Turn Over ) di RS Anisa Tangerang pada tahun 2014 sebesar 26,54\%, tahun 2015 sebesar $22,72 \%$ dan tahun 2016 sebesar $22 \%$ sedangkan di RS Pelabuhan Jakarta dilihat dari presentasi perawat yang keluar ( Turn Over ) pada tahun 2014 sebesar 30,2\%, tahun 2015 sebesar $25 \%$ dan tahun 2016 sebesar 20,6\%, beban kerja menjadi alasan terbesar keluar dari rumah sakit. Tujuan: penelitian ini untuk mengetahui perbedaan kualitas kehidupan kerja perawat dan mutu pelayanan keperawatan di instalasi rawat inap RS Anissa Tangerang dan RS Pelabuhan Jakarta. Subjek dalam penelitian ini adalah 114 perawat dan 114 pasien. Metode:Penelitian ini menggunakan metode rancangan cross-sectional. Hasil: Terdapat hubungan antara dimensi kehidupan kerja, dimensi desain kerja dan status pekerjaan dengan mutu pelayanan keperawatan di RS Anissa Tangerang, terdapat hubungan antara dimensi kehidupan kerja, dimensi desain kerja dan tingkat pendidikan dengan mutu pelayanan keperawatan di RS Pelabuhan Jakarta. Terdapat perbedaan antara kualitas kehidupan kerja perawat di rumah sakit Anissa Tangerang dan rumah sakit Pelabuhan Jakarta serta tidak terdapat perbedaan antara mutu pelayanan keperawatan di rumah sakit Anissa Tangerang dengan rumah sakit Pelabuhan Jakarta.
\end{abstract}

Kata kunci: dimensi kehidupan kerja, desain kerja, kontek kerja, dunia kerja, mutu pelayanan keperawatan

\begin{abstract}
Background: Quality work of life is an effort level of employees who can improve their personal life through their job in the work environment. The presentation of nurse out (Turn Over) in RS Anisa Tangerang in 2014 amounted to $26.54 \%$, in 2015 by $22.72 \%$ and in 2016 by 22\% while in RS Pelabuhan Jakarta seen from the presentation of the nurse out (Turn Over) in 2014 by 30.2\%, in 2015 by 25\% and in 2016 by 20.6\%, the workload that is the biggest reason to get out of the hospital. Purpose of this study to determine the differences in the quality work of life of nurses on the quality of nursing service in in patient between Anissa hospital Tangerang and Pelabuhan hospital Jakarta. The sample of are about this study are about 114 nurses and 114 patient. Method: This study employs analytical observational with cross sectional design. Result: There is relation between work life dimension, work design dimension and work status with quality of nursing service at Anissa Tangerang Hospital, there is correlation between work life dimension, work design dimension and education level with quality of nursing service at Pelabuhan Hospital Jakarta. There is difference between the quality of work life of the nurse at Anissa Tangerang hospital and the Pelabuhan Hospital Jakarta and there is no difference between the quality of nursing service in Anissa Tangerang hospital with the Pelabuhan Hospital Jakarta.
\end{abstract}

Keywords: dimension work life, design work, context working, the world of working, quality of nursing service 
Istilah kualitas kehidupan kerja (Quality of Work Life $=Q W L$ ) diperkenalkan pertamakalinya oleh Louis Davis pada tahun 1970-an ( Lokanadha Reddy M dan Mohan Reddy P., 2010). Konferensi pertama mengenai $Q W L$ dilakukan di Toronto tahun 1972 dan pada tahun itu dibentuk International Council for QWL. Para ahli mempunyai pendapat masing-masing dalam mendefenisikan kualitas kehidupan kerja, namun setelah diadakan konferensi tersebut di simpulkan bahwa pengertian kulitas kehidupan kerja adalah suatu upaya tinggi rendahnya para pegawai dapat meningkatkan kehidupan pribadi mereka melalui melaksanakan pekerjaannya di lingkungan kerjanya. Kualitas kehidupan kerja menunjukan menyenangkan atau tidak menyenangkannya pekerjaan dan lingkungan kerja bagi para pegawai yang bekerja di lingkungan pekerjaan tersebut.( Wirawan, 2015).

Setiap organisasi seperti Rumah Sakit, yang mampu memberikan kinerja terbaik dihasilkan oleh serangkaian sistem yang berlaku dalam organisasi tersebut. Sumber daya manusia merupakan salah satu faktor kunci untuk mendapatkan kinerja terbaik. Sumber daya manusia yang baik dapat dipengaruhi oleh beberapa faktor, salah satuya adalah kualitas kehidupan kerja. Kualitas kehidupan kerja dari sumber daya manusia yang baik dapat berpengaruh bagi Rumah Sakit, yaitu dapat meningkatkan kepuasan pelanggan dengan kinerja terbaik para pegawai terhadap pelayanan kesehatan. (Hafizurrachman, 2011).

Banyak faktor yang mempengaruhi peningkatan kualitas sumber daya manusia. Cascio (2010) menyebutkan bahwa ada sembilan komponen di dalam kualitas kehidupan kerja yang diharapkan dapat meningkatkan kualitas sumber daya manusia, yaitu kompensasi, pengembangan karir, keselamatan lingkungan kerja, komunikasi, keterlibatan karyawan, penyelesaian masalah, fasilitas yang tersedia, rasa bangga terhadap institusi dan rasa aman terhadap pekerjaan. Hal tersebut menjelaskan bahwa kualitas kehidupan kerja adalah cara yang tepat untuk meningkatkan kualitas sumber daya manusia. Menurut Brooks pada jurnal penelitian yang dilakukan oleh Almalki, et al. pada tahun 2012 menyebutkan bahwa kualitas kehidupan kerja kerja dapat dibagi menjadi 4 
dimensi besar, yaitu (1) Dimensi kehidupan kerja/kehidupan keluarga (work life/home life), (2) Dimensi desain kerja (work design), (3) Dimensi konteks kerja (work context), dan (4) Dimensi dunia kerja (work world).

Telah disebutkan bahwa kualitas kehidupan kerja berperan penting pada performa sumber daya manusia. Salah satu SDM terpenting dalam Rumah Sakit adalah perawat, karena selain jumlahnya yang dominan (50\%-60\% dari seluruh tenaga kerja), perawat memberikan pelayanan 24 jam sehari, selama 7 hari serta mempunyai kontak dengan pasien. Perawat adalah seseorang (seorang profesional) yang mempunyai kemampuan, tanggung jawab dan kewenangan melaksanakan pelayanan/asuhan keperawatan pada berbagai jenjang pelayanan keperawatan (Kusnanto, 2005). Seiring dengan bertambahnya tahun, jumlah perawat yang ada di Indonesia semakin bertambah. Dengan bertambahnya jumlah perawat tentunya akan menambah persaingan dalam mendapatkan suatu pekerjaan. Penilaian kinerja merupakan alat yang paling dapat dipercaya oleh manajer perawat dalam mengontrol sumber daya manusia dan produktivitas (Swanburg, 1987 dalam Nursalam, 2011). Proses penilaian kinerja dapat digunakan secara efektif dalam mengarahkan perilaku perawat, dalam rangka menghasilkan jasa keperawatan dalam kualitas dan volume yang tinggi. Bila kualitas kehidupan kerja pada karyawan menunjukkan hasil yang baik dari penilaiannya, maka akan menimbulkan dampak positif bagi Rumah Sakit, seperti meningkatnya motivasi karyawan dan mutu pelayanan keperawatan sehingga meningkatkan komitmen terhadap pekerjaan serta dapat menurunkan angka turnover karyawan dan tingkat ketidakhadiran (William and Keith dalam Anggoro, 2006). Menurut penelitian the Bernard Hodes Group didalam American Association of Colleges of Nursing pada Maret 2005 menyebutkan bahwa hasil survei di Amerika dari 138 perawat yang direkrut di Rumah Sakit, didapatkan jumlah rata-rata turnover perawat adalah $13,9 \%$ dan tingkat kekosongan perawat $16,1 \%$. Penyebab dari turnover perawat tersebut adalah karena ketidakpuasan kerja, tingginya beban kerja, dan budaya organisasi. 
Kualitas kehidupan kerja telah dijadikan sumber penelitian di beberapa bidang pendidikan, antara lain sosiologi, psikologi, manajemen, kesehatan, dan keperawatan. Beberapa tahun terakhir, kualitas kehidupan kerja telah menjadi pusat perhatian di bidang pelayanan kesehatan. Adanya ketidakpuasan pelanggan yang terjadi pada pelayanan kesehatan dapat terjadi karena kurangnya kualitas dalam memberikan pelayanan kesehatan dan rendahnya standar pada pelayanan kesehatan. Beberapa penelitian telah membuktikan bahwa kepuasan pekerja pada kualitas kehidupan kerja tidak hanya dapat meningkatkan kinerja dan mengurangi tingkat ketidakhadiran, kecelakaan kerja dan angka turnover, tetapi juga meningkatkan mutu pelayanan keperawatan dan kepuasan pada aspek hidup lainnya. Ketidakpuasan perawat yang terjadi dapat mengakibatkan beberapa masalah antara lain ketidakpuasaan terhadap pekerjaan itu sendiri, kelelahan emosional, burn out, dan turnover (Moradi, et al., 2014).

Hasil penelitian Kaihatu dan Rini (2007) menunjukkan bahwa kualitas kehidupan kerja sebesar 46,2\% di pengaruhi oleh sistem gaji atau kompensasi yang apabila diakumulasikan satu bulan nominalnya sudah melebihi standar UMR, perawat diikut sertakan dalam program jamsostek, pembagian beras diadakan setiap tiga bulan sekali, perawat yang mendapat peralatan keamanan kerja. Sedangkan sisanya sebesar 53,8\% merupakan sumbangan dari variabel lain yang merupakan faktor di luar variabel kualitas kehidupan kerja. Beberapa faktor lain yang mempengaruhi kualitas kehidupan kerja yaitu karakteristik pribadi meliputi usia dan masa kerja, kebutuhan berprestasi, pendidikan. Karakteristik pekerjaan meliputi tantangan kerja,interaksi di lingkungan kerja, identitas tugas, dan penilaian rumah sakit. Karakteristik desain pekerjaan misalnya besar kecilnya rumah sakit, bentuk rumah sakit, kehadiran serikat pekerjaan, dan tingkat pengendalian yang dilakukan rumah sakit terhadap perawat. Respon individu terhadap rumah sakit meliputi sikap individu terhadap rumah sakit, keterandalan rumah sakit, perasaan dipentingkan dalam rumah sakit, dan realisasi harapan individu dalam rumah sakit. 
Dari beberapa penjelasan diatas dapat disimpulkan bahwa peran sumber daya manusia memiliki pengaruh yang penting dalam meningkatkan kualitas rumah sakit. Ada beberapa penelitian yang telah membahas tentang kualitas kehidupan kerja perawat sebelumnya, antara lain Study of Quality of Work Life $(Q W L)$ oleh Saraji dan Dargahi pada tahun 2005, penelitian tentang Quality of Work Life Among Primary Health Care Nurses in the Jazan Region, Saudi Arabia: A Cross-sectional Study oleh Almalki, et al., dan pada tahun 2009. Selain itu, penelitian yang dilakukan di Indonesia adalah kesehatan dan kualitas kehidupan kerja terhadap mutu keperawatan di Rumah Sakit Umum Tangerang oleh Hafizurrachman, et al., pada tahun 2011, didapatkan kualitas kehidupan kerja perawat berpengaruh $6,61 \%$ terhadap kinerja perawat, selanjutnya 98,2\% kinerja perawat dipengaruhi oleh jaminan kesehatan dan kualitas kehidupan kerjanya di rumah sakit.

Tempat yang dipilih untuk melakukan penelitian ini adalah RS Anissa Tangerang dan RS Pelabuhan Jakarta. Alasan dipilihnya Rumah Sakit tersebut adalah karena mau melihat kualitas kehidupan kerja perawat di rumah sakit swasta tipe c, alasan berikutnya kenapa memilih kedua rumah sakit tersebut untuk melihat perbedaan kualitas kehidupan kerja perawat di rumah sakit di Ibukota Jakarta di RS Pelabuhan Jakarta dengan rumah sakit di daerah atau pinggiran Ibukota Jakarta di RS Anissa Tangerang. Selain itu berdasarkan hasil survei kepuasaan pasien yang dilakukan oleh pihak Rumah Sakit Anissa Tangerang per Januari 2019 didapatkan data kepuasaan pasien terhadap pelayanan keperawatan sebesar 99,5\% sedangkan hasil survei dari Rumah Sakit Pelabuhan Jakarta per Januari 2019 di dapatkan data kepuasaan pasien terhadap pelayanan keperawatan sebesar 98,5 \%, hal ini salah satu indikator untuk melihat mutu pelayanan.

Dilihat dari jumlah perawat di RS Anissa Tangerang berjumlah 81 perawat pelaksana di instalasi rawat inap sedangkan dilihat dari jumlah perawat di RS Pelabuhan Jakarta berjumlah 85 perawat pelaksana di instalasi rawat inap. Selain itu dilihat dari presentasi perawat yang keluar ( Turn Over ) di RS Anisa Tangerang 
pada tahun 2014 sebesar 26,54\%, tahun 2015 sebesar $22,72 \%$ dan tahun 2016 sebesar $22 \%$ sedangkan di RS Pelabuhan Jakarta dilihat dari presentasi perawat yang keluar ( Turn Over ) pada tahun 2014 sebesar 30,2 \%, tahun 2015 sebesar $25 \%$ dan tahun 2016 sebesar 20,6 \% ( Human Resaurse Departemen Rumah Sakit RS Anissa dan RS Pelabuhan Jakarta, 2019).

Hasil wawancara dengan beberapa kepala bidang keperawatan mengatakan bahwa rumah sakit terus menuntut perawat untuk selalu meningkatkan kinerjanya guna memperbaiki mutu keperawatan, namun hal itu tidak sebanding dengan peningkatan kualitas kehidupan kerja perawat seperti sistem penggajian sesuai dengan UMR, pengakuan prestasi dan pengembangan karir, serta jaminan kesehatan untuk perawat. Dampak dari kualitas kehidupan kerja yang tidak baik menyebabkan angka turn over yang tinggi, dari hasil wawancara dengan 5 perawat pelaksan, 5 perawat mengatakan beban kerja yang menjadi alasan terbesar keluar dari rumah sakit selain karena peraturan yang terlalu berat ( uji kompetensi) dan alasan ikut suami pindah keluar kota sedangkan hasil observasi profesi keperawatan masih dianggap sebelah mata oleh pemerintah maupun profesi lain, perawat masih diperlakukan sebagai pembantu dokter dibuktikan ketika di rumah sakit perawat masih banyak melaksanakan tugas dokter dan tugas administrasi sehingga menambah beban kerja sehingga meninggalkan peran dan fungsi keperawatan mereka.

\section{Tujuan Umum Penelitian}

Diketahuinya perbedaan kualitas kehidupan kerja perawat terhadap mutu pelayanan keperawatan di instalasi rawat inap RS Anissa Tangerang dan RS Pelabuhan Jakarta.

\section{Tujuan Khusus Penelitian}

a. Diperoleh gambaran karakteristik perawat di RS Anissa Tangerang dan RS Pelabuhan Jakarta.

b. Diperoleh gambaran tentang kualitas kehidupan kerja perawat pada empat dimensi di RS Anissa Tangerang.

c. Diperoleh gambaran tentang kualitas kehidupan kerja perawat pada empat dimensi di RS Pelabuhan Jakarta.

d. Diperoleh gambaran tentang mutu pelayanan keperawatan di RS Anissa Tangerang. 
e. Diperoleh gambaran tentang mutu keperawatan,tidak sedang bersekolah, pelayanan keperawatan di RS tidak sedang cuti dan pengalaman kerja Pelabuhan Jakarta.

f. Diperoleh hubungan kualitas kehidupan kerja perawat dengan mutu pelayanan keperawatan di RS Anissa Tangerang.

g. Diperoleh hubungan kualitas kehidupan kerja perawat dengan mutu pelayanan keperawatan di RS Pelabuhan Jakarta.

h. Terbandingkan kualitas kehidupan kerja perawat antara RS Anissa Tangerang dengan RS Pelabuhan Jakarta.

i. Terbandingkan mutu pelayanan keperawatan antara RS Anissa Tangerang dengan RS Pelabuhan Jakarta. minimal 1 tahun sehingga setelah di hitung menggunakan rumus sampel Slovin di dapatkan dari 166 populasi di dapatkan sampel yang akan diteliti berjumlah 114 perawat, hal tersebut sama dengan jumlah jumlah pasien yang akan diteliti berjumlah 114 pasien rawat inap.

Lokasi pengambilan sampel diadakan di Instalasi Rawat Inap RS Anissa Tangerang dan RS Pelabuhan Jakarta. pengambilan sampel menggunakan tehnik Random Sampling.

\section{METODE PENELITIAN}

Desain penelitian ini adalah penelitian kuantitatif dengan jenis pendekatan cross-sectional. Metode penelitian kuantitatif dalam penelitian ini menggunakan penelitian komparatif.

Pada penelitian ini, subjek yang diambil oleh peneliti adalah perawat pelaksana di instalasi rawat inap, HASIL berpendidikan minimal D3

Tabel 5.1. Distribusi Frekuensi Karakteristik Responden di Instalasi Rawat Inap RS Anissa Tangerang dan RS Pelabuhan Jakarta $(n=114)$ 


\begin{tabular}{|c|c|c|c|c|}
\hline Variabel & $\begin{array}{r}\mathbf{R S} \\
\mathbf{n}\end{array}$ & $\%$ & $\begin{array}{r}\mathbf{R S} \\
\mathbf{n}\end{array}$ & 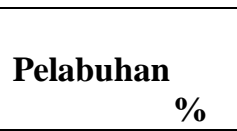 \\
\hline \multicolumn{5}{|l|}{ Jenis Kelamin } \\
\hline Laki - Laki & 8 & $14 \%$ & 8 & $14, \%$ \\
\hline Perempuan & 49 & $86 \%$ & 49 & $86, \%$ \\
\hline \multicolumn{5}{|l|}{ Tingkat Pendidikan } \\
\hline D3 & 31 & $54,4 \%$ & 39 & $68,4 \%$ \\
\hline Ners & 26 & $45,6 \%$ & 18 & $31,6 \%$ \\
\hline S2 & - & - & - & - \\
\hline \multicolumn{5}{|l|}{ Lama Kerja } \\
\hline Baru $\leq 3$ Tahun & 43 & $75,4 \%$ & 23 & $40,4 \%$ \\
\hline Lama $>3$ Tahun & 14 & $24,6 \%$ & 34 & $59,6 \%$ \\
\hline \multicolumn{5}{|l|}{ Usia } \\
\hline Lansia ( 46-65 th) & - & - & - & - \\
\hline Dewasa ( $26-45$ th) & 29 & $50,9 \%$ & 43 & $75,4 \%$ \\
\hline Remaja (17-25 th) & 28 & $49,1 \%$ & 14 & $24,6 \%$ \\
\hline \multicolumn{5}{|l|}{ Status Pekerjaan } \\
\hline Karyawan tdk tetap & 37 & $64,9 \%$ & 21 & $36,8 \%$ \\
\hline Karyawan tetap & 20 & $35,1 \%$ & 36 & $63,2 \%$ \\
\hline
\end{tabular}

Berdasarkan tabel 5.1 menunjukan bahwa $\quad$ Berdasarkan tabel 5.1 menunjukan

di RS Anissa Tangerang hasil responden yang diperoleh, jenis kelamin responden yang terbanyak adalah berjenis kelamin perempuan berjumlah $49(86 \%)$, tingkat pendidikan responden yang terbanyak adalah Diploma tiga (D3) berjumlah 31 $(54,4 \%)$, lama kerja reponden yang terbanyak adalah baru bekerja $\leq 3$ Tahun berjumlah $43(75,4 \%)$, umur responden yang terbanyak adalah dewasa (26-45 th) berjumlah 29 ( 50,9\%), status pekerjaan responden yang terbanyak adalah karyawan tidak tetap berjumlah 37 ( 64,9 $\%)$.

Tabel 5.2

Hubungan Dimensi Kehidupan Kerja Perawat, Dimensi Desain Kerja, Dimensi Kontek Kerja dan Dimensi Dunia Kerja dengan Mutu Pelayanan Keperawatan di bahwa di RS Pelabuhan Jakarta hasil responden yang diperoleh, jenis kelamin responden yang terbanyak adalah berjenis kelamin perempuan berjumlah 49 (86\%), tingkat pendidikan responden yang terbanyak adalah diploma tiga (D3) berjumlah 39 ( 68,4 \%), lama kerja reponden yang terbanyak adalah lama bekerja > 3 Tahun berjumlah 34 ( 59,6\% ), umur responden yang terbanyak adalah dewasa (26-45 th) berjumlah 43 (75,4\% ), status pekerjaan responden yang terbanyak adalah karyawan tetap berjumlah $36(63,2 \%)$.

Instalasi Rawat Inap RS Pelabuhan Jakarta

$(\mathrm{n}=57)$

\begin{tabular}{lc}
\hline \multicolumn{1}{c}{ Variabel } & P value \\
\hline Dimensi Kehidupan kerja & 0,003 \\
Demensi Desain Kerja & 0,003 \\
Dimensi Kontek Kerja & 0,190
\end{tabular}




\begin{tabular}{ll} 
Dimensi Dunia Kerja & 0,292 \\
Jenis Kelamin & 1,000 \\
Tingkat Pendidikan & 0,022 \\
Lama Kerja & 1,000 \\
Usia & 0,764 \\
Status Pekerjaan & 0,422 \\
\hline
\end{tabular}

Hasil dalam penelitian ini adalah di RS

Pelabuhan Jakarta ada hubungan antara kualitas kehidupan kerja perawat pada dimensi kehidupan kerja, dimensi desain kerja dan tingkat pendidikan dengan mutu pelayanan keperawatan.

\section{Tabel 5.3}

Perbedaan Kualitas Kehidupan Kerja Perawat di Instalasi Rawat Inap RS Anissa Tangerang dan RS Pelabuhan Jakarta

$(n=144)$

\begin{tabular}{lc}
\multicolumn{1}{c}{ Kelompok } & P value \\
\hline RS Anissa & 0,000 \\
RS Pelabuhan & 0,000 \\
\hline
\end{tabular}

Hasil dalam penelitian ini adalah ada perbedaan antara kualitas kehidupan kerja di rumah sakit Anissa Tangerang dan rumah sakit Pelabuhan Jakarta.

Tabel 5.4

Perbedaan Mutu Pelayanan Keperawatan di Instalasi Rawat Inap RS Anissa Tangerang dan RS Pelabuhan Jakarta $(\mathrm{n}=114)$

\begin{tabular}{lc}
\multicolumn{1}{c}{ Kelompok } & P value \\
\hline RS Anissa & 0,211 \\
RS Pelabuhan & 0,211 \\
\hline
\end{tabular}

Hasil dalam penelitian ini adalah tidak ada perbedaan antara mutu pelayanan keperawatan di rumah sakit Anissa Tangerang dengan rumah sakit Pelabuhan Jakarta. Semakin baik kualitas kehidupan kerja perawat maka semakin baik pula kinerja perawat sehingga semakin baik mutu pelayanan keperawatan di rumah sakit.

\section{PEMBAHASAN}

Hubungan Kualitas Kehidupan Kerja terhadap Mutu Pelayanan Keperawatan di Instalasi rawat Inap RS Anissa Tangerang.

Berdasarkan analisis Multivariat hasil penelitian yang dilakukan oleh peneliti bahwa ada tiga variabel yang berhubungan terhadap mutu pelayanan keperawatan di Rumah Sakit Anissa Tangerang yaitu variabel dimensi kehidupan kerja menunjukan hubungan yang signifikan dengan $p$ value $0,014<$ 0,05, dimensi desain kerja menunjukan hubungan yang signifikan dengan $p$ value $0,005<0,05$ dan variabel status pekerjaan menunjukan hubungan yang signifikan dengan $p$ value $0,040<0,05$. Dapat disimpulkan bahwa dari keseluruhan variabel independen, variabel dimensi kehidupan kerja yang paling berhubungan dengan mutu pelayanan keperawatan dengan $\mathrm{p}$ value $0,014<0,05$ dengan nilai $\mathrm{OR} / \operatorname{Exp}(\mathrm{B})$ terbesar yang diperoleh yaitu 5,483 
artinya dimensi kehidupan kerja keperawatan terlihat bahwa sebagian mempunyai peluang 5,483 kali besar reponden menyatakan bahwa mempengaruhi mutu pelayanan kebijakan berlibur sudah sesuai sehingga keperawatan. terjadi keseimbangan antara waktu yang dihabiskan untuk bekerja dengan waktu

Hal tersebut sesuai dengan penelitian yang dihabiskan untuk keluarga dan pada yang dilakukan oleh Gayathiri dan Instalasi Rawat Inap khususnya di Ruang Ramakrishnan pada tahun 2013 Anak yang merupakan ruang perawatan didapatkan hasil bahwa kualitas kehidupan kerja yang baik ditentukan oleh faktor objektif antara lain desain fisik dan struktural yang terdiri dari lingkungan tempat kerja dan peraturan yang ada di tempat kerja. Faktor lain yang mempengaruhi kualitas kehidupan kerja, yaitu keadaan psikologis dari para pegawai (perilaku yang positif, komitmen, dan kepuasan kerja). Hal tersebut akan berpengaruh secara langsung pada performa organisasi.

Menurut pendapat peneliti bahwa ada hubungan antara dimensi kehidupan kerja, dimensi desain kerja dan status pekerjaan dengan mutu pelayanan keperawatan, jika dimensi kehidupan kerja dan dimensi desain kerja perawat baik maka mutu pelayanan keperawatan akan baik. Di Instalasi Rawat Inap Rumah Sakit Anissa Tangerang terkait dengan Dimensi Kehidupan Kerja, Dimensi Desain Kerja dengan mutu pelayanan anak mengeluhkan beban kerja yang tinggi dan ketidakpuasan kerja. Ruang lain juga mengeluhkan masih banyak tugas non-keperawatan yang dilakukan seperti input data pasien, mengurus jaminan pasien, dan verifikasi yang seharusnya merupakan tugas bagian administrasi. Tetapi sebagian besar dari responden menyatakan kepuasan dan kebanggaan bekerja sebagai perawat. Sedangkan status pekerjaan perawat yang tidak tetap lebih baik kinerjanya terhadap peningkatan mutu pelayanan keperawatan daripada karyawan yang status pekerjaannya tetap hal ini dapat disebabkan karyawan yang tidak tetap jika ingin diangkat sebagai karyawan tetap dituntut menunjukan kinerja yang baik guna meningkatkan mutu pelayanan keperawatan.

\section{Hubungan Kualitas Kehidupan Kerja terhadap Mutu Pelayanan}




\section{Keperawatan di Instalasi rawat Inap RS Pelabuhan Jakarta.}

Berdasarkan hasil penelitian yang dilakukan oleh peneliti bahwa ada tiga variabel yang berhubungan terhadap mutu pelayanan keperawatan di RS Pelabuhan Jakarta yaitu variabel dimensi kehidupan kerja menunjukan hubungan yang signifikan dengan $p$ value $0,004<$ 0,05 dan dimensi desain kerja menunjukan hubungan yang signifikan dengan $p$ value $0,006<0,05$, tingkat pendidikan menunjukan hubungan yang signifikan dengan $p$ value $0,014<0,05$, sehingga dapat disimpulkan bahwa dari keseluruhan variabel, variabel dimensi kehidupan kerja yang paling berhubungan dengan mutu pelayanan keperawatan dengan $\mathrm{p}$ value $0,004<0,05$ dengan nilai $\mathrm{OR} / \operatorname{Exp}(\mathrm{B})$ terbesar yang diperoleh yaitu 9,476 artinya dimensi kehidupan kerja mempunyai peluang 9,476 kali berhubungan dengan mutu pelayanan keperawatan. Hal tersebut sesuai dengan penelitian yang dilakukan oleh Gayathiri dan Ramakrishnan pada tahun 2013 didapatkan hasil bahwa kualitas kehidupan kerja yang baik ditentukan oleh faktor objektif antara lain desain fisik dan struktural yang terdiri dari lingkungan tempat kerja dan peraturan yang ada di tempat kerja.
Faktor lain yang mempengaruhi kualitas kehidupan kerja, yaitu keadaan psikologis dari para pegawai (perilaku yang positif, komitmen, dan kepuasan kerja). Hal tersebut akan berpengaruh secara langsung pada performa organisasi.

Menurut pendapat peneliti bahwa ada hubungan antara dimensi kehidupan kerja, dimensi desain kerja dengan mutu pelayanan keperawatan, jika dimensi kehidupan kerja dan dimensi desain kerja perawat baik maka mutu pelayanan keperawatan akan baik. Di Instalasi Rawat Inap Rumah Sakit Pelabuhan Jakarta terkait dengan Dimensi Kehidupan Kerja, dimensi desain kerja dengan mutu pelayanan keperawatan terlihat bahwa sebagian besar reponden menyatakan bahwa kebijakan berlibur sudah sesuai sehingga terjadi keseimbangan antara waktu yang dihabiskan untuk bekerja dengan waktu yang dihabiskan untuk keluarga, responden juga mengatakan mengeluhkan masih banyak tugas nonkeperawatan yang dilakukan seperti input data pasien, mengurus jaminan pasien, dan verifikasi yang seharusnya merupakan tugas bagian administrasi. 
Tetapi sebagian besar dari responden menyatakan kepuasan dan kebanggaan bekerja sebagai perawat. dan pada Instalasi Rawat Inap khususnya di Ruang Cempaka yang merupakan ruang perawatan Wanita Dewasa mengeluhkan beban kerja yang tinggi dan ketidakpuasan kerja. Ruang lain juga mengeluhkan masih banyak tugas nonkeperawatan yang dilakukan seperti input data pasien, mengurus jaminan pasien, dan verifikasi yang seharusnya merupakan tugas bagian administrasi. Tetapi sebagian besar dari responden menyatakan kepuasan dan kebanggaan bekerja sebagai perawat. Sedangkan pada tingkat pendidikan, perawat yang tingkat pendidikannya Diploma tiga lebih baik kinerjanya dibanding dengan perawat yang memiliki tingkat pendidikan S1 Ners, hal ini dikarenakan pada saat proses perkuliahan perawat yang lulusan diploma tiga lebih banyak dan lebih sering praktek dibandingkan pada pada lulusan S1 Ners sehingga dalam pemberian asuhan keperawatan perawat lulusan diploma tiga lebih terampil dari perawat lulusan S1 Ners.

\section{Perbedaan Kualitas Kehidupan Kerja Perawat antara RS Anissa Tangerang dengan RS Pelabuhan Jakarta.}

Berdasarkan hasil penelitian yang dilakukan oleh peneliti bahwa terdapat perbedaan kualitas kehidupan kerja perawat antara RS Anissa Tangerang dengan RS Pelabuhan Jakarta. Diketahui bahwa nilai rata - rata kualitas kehidupan kerja perawat di Rumah Sakit Anissa Tangerang adalah 148,19, sedangkan rata-rata kualitas kehidupan kerja perawat di RS Pelabuhan Jakarta adalah 85,79 dengan standar deviasi 10,526 . Hasil uji statistik didapatkan nilai $\mathrm{p}=0,000$, berarti pada alpha $5 \%$ terdapat berbedaan yang signifikan antara kualitas kehidupan kerja perawat di RS Anissa Tangerang dengan kualitas kehidupan kerja Perawat di RS Pelabuhan Jakarta.

Hal tersebut sesuai dengan penelitian yang dilakukan oleh (Cascio, 2003) kualitas kehidupan kerja karyawan merupakan salah satu tujuan penting dalam memenuhi kebutuhan dan keinginan pegawai. Kualitas kehidupan kerja adalah persepsi karyawan tentang kesejahteraan dan fisiknya ketika bekerja. Ada dua pandangan mengenai maksud dari kualitas kehidupan kerja. Pertama, kualitas kehidupan kerja adalah sejumlah keadaan dan praktek dari organisasi (contoh: pengayaan penyelia yang 
demokratis, keterlibatan pekerja, dan kondisi kerja yang nyaman). Sementara yang kedua, kualitas kehidupan kerja adalah persepsi karyawan bahwa mereka ingin rasa aman, mereka merasa puas, dan mendapatkan kesempatan untuk tumbuh dan berkembang sebagai layaknya manusia

Menurut pendapat peneliti bahwa terdapat perbedaan antara kualitas kehidupan kerja perawat di RS Anissa Tangerang dengan RS Pelabuhan Jakart, hal ini terlihat dari masing-masing penilain dimensi kualitas kehidupan kerja perawat terutama pada dimensi konteks kerja point peluang pengembangan karir pada perawat, pada Rumah Sakit Anissa Tangerang pihak rumah sakit memberikan peluang kepada perawat untuk dapat melanjutkan pendidikan keperawatan ke jenjang lebih tinggi dan memberi kesempatan untuk mengikuti pelatihan - pelatihan yang diadakan pihak rumah sakit sendiri maupun di luar rumah sakit hal ini terbalik dengan Rumah Sakit Pelabuhan Jakarta yang agak sulit mendapatkan ijin untuk dapat melanjutkan pendidikan keperawatan ke jenjang yang lebih tinggi namun untuk mengikuti pelatihan pihak rumah sakit memberikan ijin.

\section{Perbedaan Mutu Pelayanan Keperawatan antara RS Anissa Tangerang dengan RS Pelabuhan Jakarta.}

Berdasarkan hasil penelitian yang dilakukan oleh peneliti bahwa tidak terdapat perbedaan mutu pelayanan keperawatan antara RS Anissa Tangerang dengan RS Pelabuhan Jakarta. Diketahui bahwa nilai rata - rata mutu pelayanan keperawatan di Rumah Sakit Anissa Tangerang adalah 74,60, sedangkan ratarata mutu pelayanan keperawatan di RS Pelabuhan Jakarta adalah 72,60 dengan standar deviasi 8,769. Hasil uji statistik didapatkan nilai $\mathrm{p}=0,211$, berarti pada alpha $5 \%$ terlihat tidak terdapat berbedaan antara mutu pelayanan keperawatan di RS Anissa Tangerang dengan mutu pelayanan keperawatan di RS Pelabuhan Jakarta.

Hal tersebut sesuai dengan penelitian yang dilakukan oleh Crosby Mutu Pelayanan kesehatan adalah yang menunjukkan tingkat kesempurnaan tingkat pelayanan kesehatan yang disatu pihak dapat menimbulkan kepuasan pada pasien sesuai dengan tingkat kepuasan rata-rata penduduk, serta pihak lain tata 
cara penyelenggaraannya sesuai dengan kode etik dan standar pelayanan profesi yang telah ditetapkan. Program penjagaan mutu adalah suatu upaya yang dilaksanakan secara berkesinambungan, sistematis, obyektif dan terpadu dalam menetapkan masalah dan penyebab masalah mutu pelayanan kesehatan berdasarkan standar yang telah ditetapkan. Menetapkan dan melaksanakan cara penyelesaian masalah sesuai dengan kemampuan yang tersedia, serta hasil yang dicapai dan menyusun cara-cara tindak lanjut untuk lebih meningkatkan mutu pelayanan.

\section{KESIMPULAN}

Di Rumah Sakit Anissa Tangerang, dari tujuh variabel hanya ada tiga variabel saja yang berhubungan dengan mutu pelayanan keperawatan yaitu dimensi kehidupan kerja, dimensi desain kerja dan status pekerjaan, Di Rumah Sakit Pelabuhan Jakarta, dari tujuh variabel hanya ada tiga variabel saja yang berhubungan dengan mutu pelayanan keperawatan yaitu dimensi kehidupan kerja, dimensi desain kerja dan tingkat pendidikan, Terdapat perbedaan kualitas kehidupan kerja antara rumah sakit Anissa tangerang dan rumah sakit
Pelabuhan Jakarta, Tidak terdapat perbedaan mutu pelayanan keperawatan antara rumah sakit Anissa tangerang dan rumah sakit Pelabuhan Jakarta.

\section{SARAN}

Meningkatkan jumlah sampel dan memperluas tempat penelitian, melakukan penelitian dengan membandingkan pengaruh kualitas kehidupan kerja dengan mutu pelayanan keperawatan di bagian/instalasi lainnya yang ada pada Rumah Sakit tersebut, menggunakan instrumen penelitian tambahan seperti observasi dan Forum Grup Diskusi (PGD) agar analisis dapat lebih mendalam, memberikan kesempatan kepada perawat untuk melanjutkan jenjang pendidikan yang lebih tinggi, meminimalisir adanya tugas non-keperawatan, perubahan sistem penggajian dan pemberian bonus yang sesuai dengan prestasi perawat, sehingga dapat memotivasi perawat untuk melakukan pekerjaan dengan lebih baik, Institusi pendidikan sebaiknya selalu berupaya melahirkan lulusan perawat yang profesional tentu melalui ilmu keperawatan yang optimal, bagi peneliti selanjutnya sebaiknya menggunakan instrumen penelitian tambahan seperti 
observasi dan Forum Grup Diskusi (PGD) agar analisis dapat lebih mendalam dan akurat.

\section{DAFTAR PUSTAKA}

Agoes Dariyo, 2003, Psikologi Perkembangan Dewasa Muda, PT. Gramedia Widiasarana Indonesia, Jakarta.

Aketch, et al. 2012, 'Effects of Quality of Work Life on Job Performance: Theoritical Perspectives and Literature Review', Current Research Journal of Social Sciences, Maxwell Scientific Organization, vol. 4, no. 5, hh. 384386.

Alligood, M.R. \& Tomey, A.N. (2006). Nursing Theorist and their work. Edition, ST. Louis: Mosby Elsevier, Inc

Almalki, et al. 2009, 'Quality of Work Life Among Primary Health Care Nurses in the Jazan Region, Saudi Arabia: A Cross-sectional Study', Human Resources for Health, vol. 10 , no. 30 , hh. 1-6.

Anas Sudijono. 2009. Pengantar Statistik Pendidikan. Jakarta: Rajawali.

Anggoro, A, 2006, Hubungan Komponen Quality of Work Life dengan Produktivitas Perawat Ruang Inap Rumah Sakit Umum Fakultas Kedokteran Universitas Kristen Indonesia Tahun 2006, Tesis Program Studi Kajian Administrasi Rumah Sakit Pascasarjana Universitas Indonesia.
Arikunto S, 2006. Prosedur Penelitian Suatu Pendekatan Praktik, Ed Revisi VI, Penerbit PT Rineka Cipta, Jakarta.

Battu dan Chakravarthy 2014, 'Quality of Work Life of Nurses and Paramedical Staff in Hospital, International Journal of Business and Administration Research Review, Vol 2, Issue 4, hh. 201-202.

Brooks dan Anderson, 2005, 'Defining Quality of Nursing Work Life', Nursing Economics Vol. 23, No. 6, hh. 322 .

Cascio, Wayne F, 2010, Managing Human Resources, Productivity, Quality of Work Life, Profits, Eight Edition, McGraw-Hill International Edition.

Depkes RI. 2008. Profil Kesehatan Indonesia. Jakarta

DPP PPNI, 2005, Standar Praktik Keperawatan, DPP PPNI, Jakarta.

Fandi Tjiptono. 2011. Pemasaran Jasa. Sleman: Bayu Media

Gayathiri dan Ramakrishnan 2013, 'Quality of Work Life-Linkage with Job Satisfaction dan Performance', International Journal of Business and Management Invention, Volume 2 Issue 1, hh.6-7.

Ghozali, Imam, 2009, Aplikasi Analisis Multivariate dengan Program SPSS, Cetakan ke IV, Badan Penerbit UNDIP, Semarang.

Hafizurrachman, et al. 2011, 'Kesehatan dan Kualitas Kehidupan Kerja 
terhadap Kinerja Perawat di Rumah Sakit Umum Tangerang', Jurnal Kesehatan Masyarakat Nasional Vol. 6, No. 2, hh.64-65.

Hair et al. (2010). Multivariate Data Analysis, Seventh Edition. Pearson Prentice Hall

Kaihatu, T.S. \& Rini, W.A. 2007. Kepemimpinan Transformasional dan Pengaruhnya Terhadap Kepuasan atas Kualitas Kehidupan Kerja, Komitmen Organisasi, dan Perilaku Ekstra Peran: Studi pada Guru-Guru SMU di Kota Surabaya. Jurnal Ekonomi Manajemen. 98.1 : 49-61.

Kusnanto, 2005, Pengantar Profesi dan Praktek Keperawatan Profesional, EGC, Jakarta.

Moradi, et al. 2014, 'Quality of Working Life of Nurses and its Related Factors', Nurs Midwifery Stud, vol. 3 , no. 2 , hh. 1 .

Nana Syaedih Sukmadinata. (2010). Metode Penelitian Pendidikan. Bandung: Remaja Rosdakarya

Nursalam, 2011, Manajemen Keperawatan: Aplikasi dalam Praktik Keperawatan Profesional Edisi 3, Salemba Medika, Jakarta.

Ramesh, et al. 2013, 'A Study on Quality of Work Life Among Nurses in a Medical College Hospital in Bangalore', National Journal of Community Medicine Volume 4 Issues 3, hh. 471-472.

Saraji dan Dargahi 2005, 'Study of Quality of Work Life (QWL)',
Iranian J Publ Health, Vol. 35, No. 4, hh. 8-9.

Silalahi, Ulber:2005. Metode Penelitian Sosial. Bandung : Unpar Press.

Srivastava dan Kanpur 2014, 'A Study on Quality of Work Life: Key Elements \& It's Implications', IOSR Journal of Business and Management Volume 16 Issue 3 Ver. 1, hh.56-57.

Sugiyono, 2013, Metode Penelitian Manajemen, CV Alfabeta, Bandung.

Sumarsono, HM Sonny, 2004, Metode Riset Sumber Daya Manusia, Penerbit Graha Ilmu, Yogyakarta. 